\title{
Identification of "Staphylococcus staphylolyticus" NRRL B-2628 as a Biovar of Staphylococcus simulans
}

\author{
GARY L. SLOAN, ${ }^{1}$ JOHN M. ROBINSON, ${ }^{1}$ AND WESLEY E. KLOOS ${ }^{2}$ \\ Department of Microbiology, The University of Alabama, University, Alabama 35486, ${ }^{1}$ and Department of \\ Genetics, North Carolina State University, Raleigh, North Carolina 27607²
}

\begin{abstract}
"Staphylococcus staphylolyticus" NRRL B-2628, the lysostaphin-producing organism, is identified as a biovar of $S$. simulans. The membership of this organism in the genus Staphylococcus is based on the guanine-plus-cytosine content of its deoxyribonucleic acid, its anaerobic growth in thioglycolate medium, the presence of teichoic acids in its cell wall, and the composition of its cell wall peptidoglycan. The identification of the organism as a member of $S$. simulans is based on its lack of production of coagulase and acetylmethylcarbinol, its carbohydrate reaction pattern, similarities in other biochemical characteristics, and the results of deoxyribonucleic acid-deoxyribonucleic acid hybridization studies.
\end{abstract}

Lysostaphin is a commercially available protein preparation obtained from culture filtrates of an organism (NRRL B-2628) designated "Staphylococcus staphylolyticus" (23). (This name is not on the Approved Lists of Bacterial Names (27), has not been validly published since 1 January 1980, and therefore has no standing in bacterial nomenclature). This preparation has been shown to be capable of specifically hydrolyzing the cell walls of other staphylococci, especially $S$. aureus $(9,22,23)$. " $S$. staphylolyticus" was originally designated a Micrococcus species by Schindler (C. A. Schindler, Ph.D. thesis, The University of Texas, Austin, 1961) and later reassigned to the genus Staphylococcus by Schindler and Schuhardt (23) on the basis of its ability to tolerate high salt concentrations and to ferment glucose anaerobically.

A large number of new species of Staphylococcus, in addition to $S$. aureus, $S$. epidermidis, and $S$. saprophyticus, have recently been described. These include $S$. cohnii, $S$. haemolyticus, and S. xylosus (24); S. warneri, S. capitis, $S$. hominis, and $S$. simulans (16); $S$. sciuri (17); $S$. intermedius (13); and $S$. hyicus (11). This report deals with the characterization of " $S$. staphylolyticus" strain NRRL B-2628 to determine its relationship among these species and offers a new nomenclature for this unique organism.

\section{MATERIALS AND METHODS}

Bacterial strains. "S. staphylolyticus" NRRL B2628 was kindly provided by W. C. Haynes (Northern Utilization Research and Development Division, Peoria, Ill.). Cultures were maintained at $4^{\circ} \mathrm{C}$ on agar slants of lysostaphin production medium (21). The type strains $S$. simulans ATCC 27848, S. haemolyticus
ATCC 29970, S. aureus ATCC 12600, and $S$. cohnii ATCC 29974, used as sources of deoxyribonucleic acid (DNA), have been described previously $(7,16$, 24). Cultures of these strains were maintained at $4^{\circ} \mathrm{C}$ on P agar slants (18).

Culture conditions. All test media were inoculated with a 24-h-old culture grown on lysostaphin production medium agar slants and were incubated at $37^{\circ} \mathrm{C}$ for 1 to 5 days, unless otherwise stated.

Morphological and colonial characteristics. Colony characteristics and cell morphology were determined as described previously (18).

Physiological characters. Oxygen and temperature requirements, motility, and $\mathrm{NaCl}$ tolerance were determined as described previously (18).

Biochemical characters. Catalase activity was determined by inoculating a small amount of plate culture in a drop of $3 \% \mathrm{H}_{2} \mathrm{O}_{2}$. The benzidine test was performed by the method of Deibel and Evans (10). The production of free coagulase was tested by the method of Fisk, as reported by Baird-Parker (1). Hemolysis was determined on sheep and human blood agar plates after 24,48 , and $72 \mathrm{~h}$ by using streak cultures. Acid production from carbohydrates was determined with filter-sterilized carbohydrates at a final concentration in phenol red broth base (Difco) of $0.5 \%$ (wt/vol). Tubes were observed for up to 1 month for acid production. Final pH in glucose-yeast extract broth was determined after 4 days of incubation. Acetylmethylcarbinol production was determined by Barritt's method (3). Phosphatase activity was detected by the method of Baird-Parker (1). The method of Lachica et al. (20) was used to determine deoxyribonuclease production and stability. Nitrate reduction was tested by the sulfanilic acid and $\alpha$-naphthylamine method (8) in nitrate tubes (Difco) incubated for $48 \mathrm{~h}$. The configuration of the lactic acid produced was determined by the method of Hohorst (14); D-lactic dehydrogenase isolated from Leuconostoc mesenteriodes ATCC 13391 was used according to the method of Schleifer and Kocur (25). The range of bacteriolytic activity of lysostaphin has been reported previously by 
Schindler and Schuhardt (23). Protein A determination was carried out as described by Hajek (13).

Lysostaphin susceptibility. For determination of lysostaphin susceptibility, washed cells were suspended in $0.05 \mathrm{M}$ tris(hydroxymethyl)aminomethane-saline buffer (21), pH 7.5, to an optical density of 1.0 at 620 nm. Lysostaphin was added to give a final concentration of $40 \mu \mathrm{g} / \mathrm{ml}$, and the mixture was allowed to react at $37^{\circ} \mathrm{C}$. Change in optical density was read at $10-\mathrm{min}$ intervals between 0 and $60 \mathrm{~min}$.

Lysozyme susceptibility. Susceptibility to lysozyme (final concentration, $600 \mu \mathrm{g} / \mathrm{ml}$ ) was determined in essentially the same manner as lysostaphin susceptibility.

Antibiotic susceptibilities. The Kirby-Bauer disk method (4) was used to determine antibiotic susceptibilities. The following antibiotic disks (Difco) were placed on a lawn of cells on Mueller-Hinton agar plates (Difco): penicillin G $(2 \mathrm{U})$, novobiocin $(5 \mu \mathrm{g})$, erythromycin $(2 \mu \mathrm{g})$, and tetracycline $(20 \mu \mathrm{g})$. Zones of inhibition were noted at $18 \mathrm{~h}$.

Cell wall preparation and analysis. Isolation and analysis of the cell wall peptidoglycan from $S$. staphylolyticus have been described previously (21). The procedure of Wolin et al. (30) was used for qualitative examination of the cell wall teichoic acids.

DNA isolation. Staphylococci were grown in a modified $\mathrm{CH}$ broth medium (26) and were lysed by procedures described previously (19). DNA was isolated and purified by the procedures of Brenner and coworkers (5) as modified by Kloos and Wolfshohl (19).

DNA:DNA hybridization. DNA reassociation reactions and the separation of single-stranded, unreacted DNA from double-stranded, hybridized DNA on hydroxyapatite were performed by the procedures described by Brenner and co-workers (5). The percent relative binding was determined by normalizing the amount of labeled DNA bound to hydroxyapatite in heterologous reactions to that bound in the homologous reaction (where labeled and unlabeled DNA are from the same organism).

Chemicals. Egg white lysozyme was purchased from Sigma Chemical Co., St. Louis, Mo.; lysostaphin (237 $\mathrm{U} / \mathrm{mg}$ ) was purchased from Schwarz/Mann, Orangeburg, N.Y.; all other chemicals were reagent or analytical grade and were obtained from commercial sources.

\section{RESULTS AND DISCUSSION}

Identification of " $S$. staphylolyticus" NRRL B2628 at the generic level. The major characteristics used here to differentiate the genera Staphylococcus and Micrococcus included the guanineplus-cytosine $(\mathrm{G}+\mathrm{C})$ content of the DNA, anaerobic growth in thioglycolate medium, the presence of teichoic acids in the cell walls, lysostaphin endopeptidase susceptibility, and differences in the cell wall peptidoglycan (2). The chemical composition of the peptidoglycan and lysostaphin susceptibility are interrelated properties. Staphylococci have glycine-rich peptidoglycans in their cell walls and are susceptible or slightly resistant to the lysostaphin endopeptidase, which is specific for glycylglycine bonds
$(6,28)$. Micrococci have a remarkably different peptidoglycan composition and are therefore resistant to the lysostaphin endopeptidase. We previously reported that " $S$. staphylolyticus" peptidoglycan contains glycine and suggested possible reasons for the organism's resistance to its own staphylolytic glycylglycine endopeptidase (21). "S. staphylolyticus" also displayed good diffuse growth in the anaerobic portion of thioglycolate medium and, as is typical of staphylococci, contained cell-wall teichoic acid. The $\mathrm{G}+\mathrm{C}$ contents of the DNAs of staphylococci are low ( 30 to $38 \mathrm{~mol} \%$ ), whereas the micrococci possess high $\mathrm{G}+\mathrm{C}$ contents (66 to $73 \mathrm{~mol} \%$ ) in their DNAs. " $S$. staphylolyticus" NRRL B-2628 had a G $+C$ content in its DNA of $35.1 \mathrm{~mol} \%$, definitely establishing it as not a member of the genus Micrococcus. On the other hand, its $\mathrm{G}+\mathrm{C}$ content is consistent with that expected for a staphylococcus.

Identification of "S. staphylolyticus" NRRL B2628 at the specific level. The production of coagulase is a major criterion in the classification of the staphylococci. " $S$. staphylolyticus" NRRL B-2628 was found to be coagulase negative. A large number of coagulase-negative species have been described recently, and the characteristics used in their classification have been used to identify " $S$. staphylolyticus" NRRL B2628. A description of this strain follows:

The cells were gram-positive cocci, 0.9 to 1.2 $\mu \mathrm{m}$ in diameter, nonmotile and nonsporeforming; they occurred singly and in pairs, short chains, and clusters, occasionally in tetrads.

Colonies on $\mathrm{P}$ agar medium were 7.1 to 7.5 $\mathrm{mm}$ in diameter, raised, gray-white, and entire.

The organism was facultatively anaerobic. It demonstrated the fermentation of glucose by lowering the $\mathrm{pH}$ of glucose-yeast extract broth from 6.8 to 4.7 after anaerobic incubation. Both $\mathrm{L}$ - and D-lactic acid isomers were produced, with the L-isomer constituting $92 \%$ of the total.

The organism grew well in $10 \% \mathrm{NaCl}$ and had weak growth at an $\mathrm{NaCl}$ concentration of $15 \%$. The optimal growth range was 25 to $40^{\circ} \mathrm{C}$. It grew well at 15 and $45^{\circ} \mathrm{C}$.

The organism gave positive reactions for catalase and the benzidine test and demonstrated weak hemolysis on sheep blood and good hemolysis on human blood. Coagulase and acetylmethylcarbinol were not produced.

The organism reduced nitrates, demonstrated phosphatase activity, and produced a heat-stable deoxyribonuclease.

Acid was produced aerobically from glucose, fructose, lactose, sucrose, glycerol, mannose, trehalose, ribose, and galactose. No acid was produced from mannitol, maltose, rhamnose, xylose, arabinose, turanose, gentiobiose, cellobiose, melezitose, xylitol, sorbitol, inositol, sali- 
cin, adonitol, dulcitol, arabitol, erythritol, erythrose, raffinose, melibiose, fucose, tagatose, lyxose, or sorbose.

The organism possessed good bacteriolytic activity, producing the staphylolytic lysostaphin endopeptidase and an endo- $\beta-N$-acetylglucosaminidase (hexosaminidase) which lyses members of the genus Micrococcus $(15,29)$. It also produced an acetylmuramic acid-L-alanine amidase which appears not to be bacteriolytic per se but capable of acting only on previously solubilized peptidoglycan (29).

The organism was resistant to lysozyme and penicillin. The organism was resistant to lysostaphin under conditions in which lysostaphin was produced (21). It was susceptible to streptomycin, novobiocin, erythromycin, and tetracycline.

TABLE 1. Character differences between " $S$. staphylolyticus" NRRL B-2628 and the type strain (ATCC 27848) of $S$. simulans

\begin{tabular}{|c|c|c|}
\hline Characteristic & $\begin{array}{l}\text { S. simulans ATCC } \\
27848\end{array}$ & $\begin{array}{l}\text { "S. staphylo- } \\
\text { lyticus" } \\
\text { NRRL B-2628 }\end{array}$ \\
\hline $\begin{array}{l}\text { Hemolysis on sheep } \\
\text { blood }\end{array}$ & $-a$ & + \\
\hline Phosphatase & Weak & + \\
\hline DNase & Weak & + \\
\hline $\begin{array}{l}\text { Growth with } 15 \% \\
\mathrm{NaCl}\end{array}$ & $-b$ & Weak \\
\hline \multicolumn{3}{|l|}{$\begin{array}{l}\text { Acid produced aero- } \\
\text { bically from: }\end{array}$} \\
\hline Maltose & Weak $^{c}$ & - \\
\hline Mannitol & $+^{d}$ & - \\
\hline Galactose & $-^{e}$ & + \\
\hline Mannose & $-f$ & + \\
\hline Teichoic acid type & $\begin{array}{l}\text { Glycerol }+ \\
\text { galactosamine }\end{array}$ & Glycerol \\
\hline \multicolumn{3}{|c|}{$\begin{array}{l}\text { Peptidoglycan } \\
\text { (mol/mol of lysine) }\end{array}$} \\
\hline Serine & 0.2 & 1.3 \\
\hline Glycine & 4.9 & 2.3 \\
\hline $\begin{array}{l}\text { Lysostaphin suscep- } \\
\text { tibility }\end{array}$ & $\mathbf{S}$ & $\mathbf{R}$ \\
\hline $\mathrm{G}+\mathrm{C}$ content (mol\%) & $34.09^{8}$ & 35.1 \\
\hline
\end{tabular}

${ }^{a}$ Data in this and the following footnotes are from Kloos and Schleifer (16). Fifty-four percent of $S$. simulans strains tested showed weak hemolysis of sheep blood.

${ }^{b}$ Seventy-seven percent of $S$. simulans strains tested showed weak growth in $15 \% \mathrm{NaCl}$.

c Sixty-nine percent of $S$. simulans strains tested showed no fermentation of maltose.

${ }^{d}$ Eight percent of $S$. simulans strains tested showed no fermentation of mannitol.

e Eight percent of $S$. simulans strains tested showed fermentation of galactose.

$f$ Seventy-seven percent of $S$. simulans strains tested showed fermentation of mannose.

${ }_{8}$ The range of the $\mathrm{G}+\mathrm{C}$ contents of the DNAs of the strains of $S$. simulans tested was 34.0 to $37.2 \mathrm{~mol} \%$.
TABLE 2. Reassociation reactions of [methyl $-{ }^{3} \mathrm{H}$ ] thymidine-labeled DNA from type strains of some representative Staphylococcus species with unlabeled DNA from " $S$. staphylolyticus" NRRL B-2628

\begin{tabular}{|c|c|c|}
\hline $\begin{array}{c}\text { Source of labeled } \\
\text { DNA }\end{array}$ & $\begin{array}{l}\text { Reaction } \\
\text { temp (C) }\end{array}$ & $\begin{array}{c}\% \text { Relative binding of } \\
\text { labeled DNA to unlabeled } \\
\text { "S. staphylolyticus" NRRL } \\
\text { B-2628 DNA }{ }^{a}\end{array}$ \\
\hline S. simulans & 55 & $100^{b}$ \\
\hline ATCC 27848 & 70 & 82 \\
\hline $\begin{array}{l}\text { S. haemolyticus } \\
\text { ATCC } 29970\end{array}$ & 70 & 6 \\
\hline $\begin{array}{l}S . \text { aureus } \\
\text { ATCC } 12600\end{array}$ & 70 & 4 \\
\hline $\begin{array}{l}\text { S. cohnii } \\
\text { ATCC } 29974\end{array}$ & 70 & 7 \\
\hline
\end{tabular}

a The actual binding of labeled DNA fragments to unlabeled DNA from the same source (homologous reactions) was $81 \pm 7 \%$.

${ }^{b}$ Relative binding data represent the average of duplicate reassociation reactions.

The organism contained peptidoglycan of the type L-Lys-Gly $2.3, \mathrm{~L}-\mathrm{Ser}_{1.3}$ (21). The cell wall teichoic acid contained glycerol, with no other neutral sugar or additional amino sugar detected. No protein A was found associated with the cell wall.

The $\mathrm{G}+\mathrm{C}$ content of the DNA was $35.1 \mathrm{~mol} \%$.

As with $S$. simulans, " $S$. staphylolyticus" is distinguished from other staphylococci by its lack of acetylmethylcarbinol production, carbohydrate reaction pattern, and cell wall composition. A large number of other properties demonstrated that this organism is closely related to or identical with $S$. simulans. Differences between "S. staphylolyticus" and the type strain of $S$. simulans (ATCC 27848) are summarized in Table 1 . As can be seen in Table 1 , the only major differences between " $S$. staphylolyticus" and the various strains of $S$. simulans that have been characterized were in the composition of the cell wall. This is not surprising considering that " $S$. staphylolyticus" produces an enzyme that lyses most other staphylococcal cells, including $S$. simulans (16).

Kloos and Schleifer reported that several properties of $S$. simulans overlap with properties of human strains of $S$. aureus (16). Likewise, several characteristics of " $S$. staphylolyticus" NRRL B-2628 suggest that this strain may be phenotypically related to $S$. aureus (J. M. Robinson, C. J. Oliver, J. K. Hardman, and G. L. Sloan, Abstr. Annu. Meet. Am. Soc. Microbiol. 1977, K168, p. 214). The heat-stable deoxyribonuclease activity found in this strain would appear to be unusual for a coagulasenegative staphylococcus. However, Gramoli and Wilkinson (12) recently isolated some heat- 
stable, deoxyribonuclease-positive strains of $S$. simulans. This property does not appear to be limited to $S$. aureus.

The results of DNA reassociation reactions performed at the stringent criterion $\left(70^{\circ} \mathrm{C}\right)$ indicate that strain NRRL B-2628 labeled as " $S$. staphylolyticus" is a member of the species $S$. simulans (Table 2). This contention is supported further by the high relative binding of labeled $S$. simulans DNA at the optimal criterion $\left(55^{\circ} \mathrm{C}\right)$. Considering the high binding of $S$. simulans DNA to the DNA of strain NRRL B-2628, it would not be necessary to examine DNA relatedness to other species, except perhaps to serve as suitable controls. As can be seen from the data in Table 2, strain NRRL B-2628 is not closely related to $S$. haemolyticus, $S$. aureus, or $S$. cohnii, which represent several divergent groups.

On the basis of the results presented here, we suggest that "Staphylococcus staphylolyticus" NRRL B-2628 be reclassified as Staphylococcus simulans biovar staphylolyticus. This properly classifies this organism with regard to the new species which have been described yet retains its identity as the lysostaphin-producing organism.

\section{ACKNOWLEDGMENTS}

This study was supported in part by Public Health Service Institutional Biomedical Research Support Grant PHS-07151 from the National Institutes of Health and by faculty research grants 972 and 1038 from the University of Alabama Research Grants Committee (to G.L.S.) and by North Carolina Agricultural Research Service Project No. NCO 3666 (to W.E.K.).

\section{REPRINT REQUESTS}

Address reprint requests to: Dr. Gary L. Sloan, Department of Microbiology, The University of Alabama, University, AL 35486 .

\section{LITERATURE CITED}

1. Baird-Parker, A. C. 1963. Classification of micrococci and staphylococci based on physiological and biochemical tests. J. Gen. Microbiol. 30:409-427.

2. Baird-Parker, A. C. 1974. Staphylococcus, p. 483-489. In R. E. Buchanan and N. E. Gibbons (ed.), Bergey's manual of determinative bacteriology, 8th ed. The Williams \& Wilkins Co., Baltimore.

3. Barritt, M. M. 1936. The intensification of the VogesProskauer reaction by the addition of alpha-naphthol. J. Pathol. Bacteriol. 63:65-72.

4. Bauer, A. W., W. M. M. Kirby, J. C. Sherris, and M. Turck. 1966. Antibiotic susceptibility testing by a standardized single disc method. Am. J. Clin. Pathol. 45:493496.

5. Brenner, D. J., G. R. Fanning, A. Rake, and K. E. Johnson. 1969. A batch procedure for thermal elution of DNA from hydroxyapatite. Anal. Biochem. 28:447-459.

6. Browder, H. P., W. A. Zygmunt, J. R. Young, and P. A. Tavormina. 1965. Lysostaphin: enzymatic mode of action. Biochem. Biophys. Res. Commun. 19:383-389.

7. Cowan, S. T., C. Shaw, and R. E. O. Williams. 1954. Type strain for Staphylococcus aureus Rosenbach. J. Gen. Microbiol. 10:174-176.

8. Cowan, S. T., and K. J. Steel. 1965. Manual for the identification of medical bacteria. Cambridge University Press, London.

9. Cropp, C. B., and E. F. Harrison. 1964. The in vitro effect of lysostaphin on clinical isolates of Staphylococcus aureus. Can. J. Microbiol. 10:823-828.

10. Deibel, R. H., and J. B. Evans. 1960 . Modified benzidine test for the detection of cytochrome-containing respiratory systems in microorganisms. J. Bacteriol. 79:356-360.

11. Devriese, L. A., V. Hájek, P. Oeding, S. A. Meyer, and K. H. Schleifer. 1978. Staphylococcus hyicus (Sompolinsky 1953) comb. nov. and Staphylococcus hyicus subsp. chromogenes subsp. nov. Int. J. Syst. Bacteriol. 28:482-490

12. Gramoli, J. L., and B. J. Wilkinson. 1978. Characterization and identification of coagulase-negative, heat-stable deoxyribonuclease-positive staphylococci. J. Gen. Microbiol. 105:275-285.

13. Hájek, V. 1976. Staphylococcus intermedius, a new species isolated from animals. Int. J. Syst. Bacteriol. 26:401408.

14. Hohorst, H. J. 1962. L-(+)-lactate. Determination with lactic dehydrogenase and DPN, p. 266-270. In H. U. Bergmeyer (ed.), Methoden der enzymatischen analyse. Verlag Chemie, Weinheim.

15. Iverson, O. J., and A. Grov. 1973. Studies on lysostaphin. Separation and characterization of three enzymes. Eur. J. Biochem. 38:293-300.

16. Kloos, W. E., and K. H. Schletfer. 1975. Isolation and characterization of staphylococci from human skin. II. Descriptions of four new species: Staphylococcus warneri, Staphylococcus capitis, Staphylococcus hominis, and Staphylococcus simulans. Int. J. Syst. Bacteriol. 25:62-79.

17. Kloos, W. E., K. H. Schleifer, and R. F. Smith. 1976 Characterization of Staphylococcus sciuri sp. nov. and its subspecies. Int. J. Syst. Bacteriol. 26:22-37.

18. Kloos, W. E., T. G. Tornabene, and K. H. Schleifer. 1974. Isolation and characterization of micrococci from human skin, including two new species: Micrococcus lylae and Micrococcus kristinae. Int. J. Syst. Bacteriol. 24:79-101.

19. Kloos, W. E., and J. F. Wolfshohl. 1979. Evidence for deoxyribonucleotide sequence divergence between staphylococci living on human and other primate skin. Curr. Microbiol. 3:167-172.

20. Lachica, R. V. F., C. Genigeorgis, and P. D. Hoeprich. 1971. Metachromatic agar-diffusion methods for detecting staphylococcal nuclease activity. Appl. Microbiol. 21:585-587.

21. Robinson, J. M., J. K. Hardman, and G. L. Sloan. 1979. Relationship between lysostaphin endopeptidase production and cell wall composition in Staphylococcus staphylolyticus. J. Bacteriol. 137:1158-1164.

22. Schindler, C. A. 1966 . Staphylococcal strains with relation to lysostaphin sensitivity. Nature (London) 209:13681369.

23. Schindler, C. A., and V. T. Schuhardt. 1964. Lysostaphin: a new bacteriolytic agent for the Staphylococcus. Proc. Natl. Acad. Sci. U.S.A. 51:414-421.

24. Schleifer, K. H., and W. E. Kloos. 1975. Isolation and characterization of staphylococci from human skin. I. Amended descriptions of Staphylococcus epidermidis and Staphylococcus saprophyticus and descriptions of three new species: Staphylococcus cohnii, Staphylococcus haemolyticus, and Staphylococcus xylosus. Int. J. Syst. Bacteriol. 25:50-61.

25. Schleifer, K. H., and M. Kocur. 1973. Classification of staphylococci based on chemical and biochemical properties. Arch. Mikrobiol. 93:65-85.

26. Shalita, A., I. Hertman, and S. Sarid. 1977. Isolation and characterization of a plasmid involved with enterotoxin B production in Staphylococcus aureus. J. Bacteriol. 129:317-325.

27. Skerman, V. B. D., V. McGowan, and P. H. A. Sneath (ed.). 1980. Approved lists of bacterial names. Int. J. Syst. Bacteriol. 30:225-420. 
28. Sloan, G. L., E. C. Smith, and J. H. Lancaster. 1977. Lysostaphin endopeptidase-catalysed transpeptidation reactions of the imino-transfer type. Biochem. J. 167:293296.

29. Wadström, T., and O. Vesterberg. 1971. Studies on endo$\beta-N$-acetylglucosaminidase, staphylolytic peptidase and
$\mathrm{N}$-acetylmuramyl-L-alanine amidase in lysostaphin and from Staphylococcus aureus. Acta Pathol. Microbiol. Scand. Sect. B 79:248-264.

30. Wolin, M. J., A. R. Archibald, and J. Baddiley. 1966. Changes in wall teichoic acid resulting from mutations of Staphylococcus aureus. Nature (London) 209:484-486. 